\title{
MIHÓK RICHÁRD
}

\section{A királyházai Nyalábvár}

Az 1241-es mongol-tatár betörést követően, Magyarország területén megkezdődött a kőből készült várak építése. A határterületeken elterülő vármegyék stratégiailag fontos pontjain sorra épültek fel az új erődítmények. A határvédő funkciót betöltő várak egyike volt a Nyalábvár. A Királyháza mellet elterüló magányos dombtetőn egykor oly impozánsan álló vár volt Ugocsa vármegye és a Tisza felső folyásának egykori legfőbb védelmezője. Visk várának elpusztulása után, mikor még a Huszt vára fel sem épült, a tiszai hajózás és főképp a só szállítási útvonalának védelmét és ellenőrzését Nyalábvár töltötte be. Királyháza a gyepüvonal mentén helyezkedett el, és földrajzi helyzetéböl adódóan, a Toronyaihágó irányából a Nagyág folyó mentén érkező ellenséget a Huszti-kapunál sikeresen meg tudta állítani. A másik fontos célja a Tisza felügyelete volt, ami a vártól 300 400 méterre található. Ugocsa vármegye közigazgatási egységként, eme korai szakaszban kezdett el kiformálódni. A királyi hatalom gyakorlásához szükségessé vált egy erős vár megépítése, ami egy biztos központot jelenthetett.

Nyalábvár történetírásának kezdete a 19. század végére tehető. Komáromy András „Nyalábvár és uradalma" címü munkája öleli fel a vár és a hozzá tartozó birtokok történetét, mely azóta is témával kapcsolatos munkák alapjául szolgál. A 20. század folyamán a vár külön történetével kapcsolatos munkák nem ismertek, csak a 21. század elején láttak napvilágot újabb írások, melyek régészeti adatokat szolgáltatnak. $^{2}$

Királyházát az oklevelek először 1262-ben említik. ${ }^{3}$ A dokumentum mint „domus regalis”-t említi, mely a király szálláshelyéuil szolgált itt tartózkodása alkalmával. ${ }^{4}$ Komáromy szerint a magyar királyok gyakran vadásztak Ugocsa erdeiben és kényelmük biztosítása érdekében építettek egy fából készült házat. ${ }^{5}$ Szerinte maga a latin „domus regalis” megnevezés is erről árulkodik, vagyis egy egyszerü, valószínüleg fából készült lakóházra utal. 1272-ben V. István kiváltságokban részesítette az itt élö, zömében szász vendégnépeket: „hospites nostri

\footnotetext{
${ }^{1}$ KOMÁROMY ANDRÁS: Ugocsa vármegye a történelemben. Válogatott írások. Szerk.: KOBÁLYNÉ-HOMOKI ILONA. Ungvár, 2001. (A továbbiakban KOMÁROMY: i. m.).

${ }^{2}$ ПРОХНЕНКО, И.А., МОЙЖЕС, В.В., ГОМОЛЯК, Е.М: Результаты исследования Королёвского замка в 2011 году Карпатика. Випуск 40. (2011) 213-233 с.

${ }^{3}$ KOMÁROMY: i. m., 17.

${ }^{4}$ Codex diplomaticus Regni Hungariae ecclesiasticus ac civilis. Ed. FEJÉR, GEORGIUS, Budae, 1829. 176. (A továbbiakban FEJÉR: i. m.)

${ }^{5}$ KOMÁROMY: i. m., 18.
} 
de villa Felzaz, apud domum nostri videlicet in Ugocha constituti." azért volt szükség, mivel Komáromy szerint a király módfelett igénybe vette az ott lakók munkaerejét. ${ }^{7}$ Komáromy szerint Nyalábvár a IV. László és a III. András idején zajló polgárháborúk alatt épülhetett. Létezésének bizonyítékaként azt az 1290. június 18-án László király által kibocsátott oklevelet említi, mely Ubul fia Mihályt ispánná nevezi ki, és megparancsolja a nemeseknek, várjobbágyoknak és várnépeknek, hogy neki és két fiának mindenkor engedelmeskedjenek. Komáromy: „Tudomásunk szerint ez a legelső és egyetlen oklevél, mely ugocsai várjobbágyokról, és várnépekröl szól s talán argumentuma a történeti emlékeinkben nem sokkal utóbb feltünő Nyalábvár egykori létének." " Oklevelek hiánya miatt a vár építésének idejét pontosan meghatározni igen nehéz. Komáromy megemlít egy 1290. június 18-án kelt dokumentumot, mely várnépeket említ Ugocsa vármegyében. ${ }^{9}$ Saját véleményem szerint V. István korában kezdték építeni a várat és IV. László uralkodása alatt, vagy III. András uralkodásának kezdetén készülhetett el.

Történelme folyamán gyakran cserélt gazdát és sok csatát megért a királyházi Nyalábvár. Megépülése után, valószínűleg királyi kézben volt. Erről árulkodik az a dokumentum, mely 1307. szeptember 7-én kelt, melyben Károly Róbert király az Ugocsa vármegyei Szőlőst Tamás comes fiának, Borsa Bekének adományozza. ${ }^{10} \mathrm{Az}$ oklevél nem ejt arról szót, hogy vár tartozna az adományhoz, vagy, hogy Nyalábvára is részét képezné. A következő évből ismeretes egy dokumentum, mely szőlősi várnagyot említ, bizonyos Mihály fiát Istvánt, ${ }^{11}$ aki az újonnan épített szőlősi vár ura volt. A szőlősi Kankóvár helyzetéből adódóan nem tudta felügyelni a Tisza bal partján élő hospes lakosságot, ezért is gondolhatunk arra, hogy a király nem hagyta felügyelet nélkül ezen területet. Ékes példája ennek az 1300-ban ${ }^{12}$ Ugocsáról lecsatolt viski vár, melyet a máramarosi hospesek védelmére választottak le a vármegyéről. Borsa Beke 1314 nyarán szembeszállt Károly Róberttel. Engel Pál úgy vélte: „Legegyszerübb, ha ezt a pártütést valamiképpen az 1314. augusztusszeptember táján tartott országgyüléssel hozzuk összefüggésbe." ${ }^{13}$ Feltevése szerint a király és a bárók végleges szembefordulása ezen a gyülésen következett be. Borsa Beke elfoglalta Nyalábvárat, ahol az ugocsai nemeseket maga köré véve, hadakozott a királyi csapatok ellen. Az ostrom nagy valószínűséggel 1315 tavaszán lehetett, melyben Ung és Bereg vármegye nemesei vettek részt Tamás mester, munkácsi várnagy vezetésével. ${ }^{14}$ Nyalábvárat újra építették, és úgy tünik, hogy Tamás mester kapta meg, Bereg és Ugocsa vármegye ispánságával együtt. Egy 1320. november

\footnotetext{
${ }^{6}$ Uo. 17., FEJÉR: i. m., 177.

${ }^{7}$ KOMÁROMY: i. m., 17.

${ }^{8}$ KOMÁROMY: i. m., 19.

${ }^{9}$ Uo. 19.

${ }^{10}$ Codex diplomaticus Hungaricus Andegavensis. Anjoukori okmánytár. I. (1301-1321). Szerk.: NAGY IMRE. Bp., 1878. 131. (A továbbiakban AO).

${ }^{11}$ AO I., 149.

${ }^{12}$ Szentpétery Imre, Borsa Iván: Az Árpádházi királyok okleveleinek kritikai jegyzéke II. kötet 4. füzet 1290-1301 (Magyar Országos Levéltár kiadványai, II. Forráskiadványok 13.). Bp., 1987. 248.

${ }^{13}$ ENGEL PÁL: Beilleszkedés Európába a kezdetektől 1440-ig. Bp., 1990. 254.

${ }^{14}$ KOMÁROMY: i. m., 21.
} 
25-én kelt dokumentum tesz említést Nyalábvár újjáépítéséről. ${ }^{15}$ Ezt az oklevelet Komáromy 1315-re datálja, de nem indokolja meg az évszámmódosítást. ${ }^{16}$ Tamás mestertől az újjáépített várat a király elvette, és más birtokokkal kárpótolta. ${ }^{17}$ Nyalábvár addig volt fontos a királynak, míg a huszti vár 1350 környékén fel nem épült. $^{18}$

1355. december 15-én a Nyalábvárhoz tartozó Nagy-Szász (Szászfalu), Királyháza, Ardó (Feketeardó) és Veréce falvak lakossága azzal fordult Lajos királyhoz, hogy a következő kiváltságokban részesítse őket: „Az említett királyi népek és jobbágyok falunagyot és plébánost maguk közül szabadon választhatnak, akit csak akarnak, kivéve a Nogzaz-i plébániát, amelynek adományozását a király maga és utódai részére tartja fenn... Ajándék címén (pro munera) ugyanezeken a napokon ispánjuknak minden ház után egy köböl sört, két kalácsot (tortas), egy tyúkot adnak, továbbá mindegyik falu népe karácsonykor az ispánjuknak vagy várnagyuknak egy fertö értékü ajándékot, vagy egy fertöt ad. Gabonaadót (akones) zabban és búzában Nyaláb várához a régi szokás szerint mindenféle újítás nélkül fizetnek... A Tiszán levö Kyralreue nevü révnél (in portu Tycie) szedni szokott vám alól használat alatt levö földjeik után (ratione terrarum ipsarum usualium) mentesülnek. Parochiális egyházaik korábbi szabadságukban élhessenek, a nyalábi várnagyok háborgatása nélkül. A makkos erdöket, hegyeket, vizeket, patakokat és halastavakat (piscinas) - kivéve a királyi jogokat - ugyanúgy használják, mint eddigelé...", 19 amit a király teljesít is. A dokumentumból kitünik, hogy a királynak továbbra is fontos volt a Nyalábvár és a hozzá tartozó uradalom, mivel a felsorolt gazdasági és adminisztratív kérések, tetemes előjoggal ruházták fel az ott élőket. 1357. december 28-án, Erzsébet királyné parancslevelet küld Oliver mesternek, Ugocsa vármegye ispánjának és Nyalábvár várnagyának, hogy a király által kiadott kiváltságokban a négy falu lakosságát biztosítsák. ${ }^{20}$

Miután felépült a huszti vár, amely a máramarosi öt koronavárost - és alkalomadtán 3-4 vármegye lakosságát is - védelmezni tudta, Nyalábvár hátérbe szorult. ${ }^{21}$ Ezért 1378. augusztus 20-án Nagy Lajos király, a Moldvából elűzött Szász vajda fiainak adományozta, akik már a máramarosi ispáni széket is birtokolták. ${ }^{22}$ Komáromy szerint: „Drág vajda eröszakos, ragadozó ember volt, ki egy csöppet sem törödött jobbágyainak királyadta privilégiumával s nem az ök hasznát, de a magáét nézte... Ugy látszik, hogy a régi királyi vendégek zöme ebben az idöben el is költözködött Nyaláb tartományból és a máramarosi korona városokban talált új

\footnotetext{
${ }^{15}$ Hazai oklevéltár 1234-1536. Codex diplomaticus patriae. Szerk.: NAGY IMRE, DEÁK FARKAS, NAGY GYULA, Bp., 1879. 182. sz. (A továbbiakban HOKL), A nagykállói Kállaycsalád levéltára I. kötet. Bp., 1943. 142. sz.

${ }^{16}$ KOMÁROMY: i. m., 22.

${ }^{17}$ Uo. 22.

${ }^{18}$ Uo. 25.

${ }^{19}$ A Perényi család levéltára 1222-1526 (Magyar Országos Levéltár kiadványai, II. Forráskiadványok 44.). Szerk.: Tringli István. Bp., 2008. 86. sz. (A továbbiakban Perényi $\mathrm{Lt})$.

${ }^{20}$ Uo. 92. sz.

${ }^{21}$ KOMÁROMY: i. m., 25.

${ }^{22}$ Uo. 27.
} 
hazát. A földesurak részint a maguk oláh jobbágyit, részint az akkor tájban beköltözzött ruthéneket telepítették helyükbe. ${ }^{23}$ Nem telt el sok idő és Drág vajda megszerezte az ugocsai ispáni széket is. 1396-ban Drág vajdának vitás ügye támadt Nagymihályi Jánossal, aki jogot formált arra a 10 hordó borra, melyet Szőlös volt hivatott adózni évenként Nyalábvárnak. ${ }^{24}$ A perlekedés odáig ment, hogy a király 1399-ban Szőlőst Perényi Péter székely ispánnak - aki nagy kölcsönzője volt a királynak -, adományozta. ${ }^{25}$

1402. június 25-én kelt dokumentum szerint ${ }^{26}$ Drág halála után Szász vajda unokái összevesztek Nyalábvár birtoklásán, ami ekkor Drág fiai György, Sandrinus, valamint János fia László birtokában volt. Balk vajda fiai maguknak szerették volna a nyalábi uradalmat, ezért Zsigmond királyhoz fordultak igazságszolgáltatásért. A király elrendelte, hogy a perlekedő felek mutassák fel az adományleveleket, de ennek egyik fél sem tudott eleget tenni ${ }^{27}$ így nagy valószínüséggel elvesztek ezek az okiratok. A király Perényi Pétert bízta meg az eljárás további vizsgálatával, mivel a Drág fiak nem tudták felmutatni az adománylevelet, Nyalábvárat saját magának kérte fel. ${ }^{28} 1405$. március 12-én a király hivatalosan is Perényi Péternek adományozta Nyalábvárat és a hozzá tartozó birtokokat. ${ }^{29}$ Véleményem szerint a vár odaajándékozásában az is közre játszott, hogy a Perényi család köztudottan sok esetben biztosított kölcsönöket a királynak. A birtokok ügyével kapcsolatban már 1405. június 24-én vita támadt Perényi Péter és Drág vajda özvegye között Terebes birtoklása ügyében. ${ }^{30} \mathrm{~A}$ király ez ügyben is ismét Perényi Péter javára döntött.

Perényi Péter szálláshelyét Nyalábvárba rendezte be, s innen igazgatta a vármegyét és birtokait. Erről tanúskodik az is, hogy 1416. március 25 -én,$^{31} 1418$. március 6-án, ${ }^{32}$ 9-én ${ }^{33}$ és 19 -én ${ }^{34}$ Nyalábvárából intézte leveleit, különbözö vitás és adminisztratív ügyekben.

Ebben az időben virágzott a vár és a környék gazdasága, mivel jó búza- és szőlőtermő vidék volt. ${ }^{35}$ Továbbá ismeretes egy 1423-ból való oklevél, melyben Perényi Péter utasítást ad ki a révek birtokosainak, hogy azok ne vámolják meg Oláh

\footnotetext{
${ }^{23}$ Uo. 27., SZABÓ ISTVÁN: Ugocsa megye. Bp., 1940. 182.

${ }^{24}$ KOMÁROMY: i. m., 28.

${ }^{25}$ Uo. 28.

${ }^{26}$ Zsigmondkori oklevéltár II. (1400-1410): Első rész (1400-1406) (Magyar Országos Levéltár kiadványai, II. Forráskiadványok 3.) Összeállította MÁLYUSZ ELEMÉR. Bp., 1954. 1740. sz. (A továbbiakban ZSO).

${ }^{27}$ KOMÁROMY: i. m., 29.

${ }^{28}$ Uo. 30.

${ }^{29}$ C. TÓTH NORBERT. A leleszi konvent statutoriae sorozatának 1387-1410 közötti oklevelei. (Pótlás a Zsigmondkori oklevéltár I.-II. köteteihez.) (A Szabolcs-Szatmár-Bereg Megyei Levéltár kiadványai II. Közlemények 36.) Nyíregyháza, 2006. 77.

${ }^{30}$ Uo. 81.

${ }^{31}$ ZSO V. 1690. sz.

${ }^{32}$ Uo. VI. 1598. sz.

${ }^{33}$ Uo. 1610. sz.

${ }^{34}$ Uo. 1662. sz.

${ }^{35}$ KomÁromy: i. m., 31.
} 
Miklós nevü emberét, aki lovakat hajt Pest megyéből Nyalábvárba. ${ }^{36}$ Az említett dokumentum enged arra következtetni, hogy fejlett kereskedelemmel rendelkezet a Nyaláb várához tartozó birtokok, illetve Ugocsa vármegye is. Továbbá kiderül az is, hogy a vár nem csak erődítményként funkcionált, de a környék adminisztrációs központja, és kereskedelmi gócpontként müködött.

A Drág fiak és a Perényiek között továbbra is folyt a perlekedés, mivel Nagy Lajos király a várat és hozzá tartozó birtokokat apjuknak adományozta. 1424-ben a Perényi Péter meghal, és ekkor Drág vajda fiai, György és Sandrinus, vissza szeretnék szerezni Nyalábvárat. 1424. augusztus 28-án „László pap a Drág fiak nevében a váradi konvent elött, felszólitja Zsigmond királyt, hogy Nyaláb várat és a hozzá tartozó birtokokat el ne adományozza Perényi Péter fiainak, Jánosnak és Miklósnak. "37 Ám a király nem vette figyelembe a felszólítást.

Perényi Péter fiai, apjukkal ellentétben, nem tudtak jól gazdálkodni, mert hamarosan Nyalábvárat is zálogba adják. ${ }^{38}$ 1447. október 20-án Perényi Miklós a váradi káptalan előtt tiltakozik több birtok, többek között Nyalábvár zálogosítása ellen. ${ }^{39}$ Komáromy arról számol be, hogy „Ebben az időben Nyaláb várnak elég dicstelen szerep jutott. Valóságos rabló fészek volt s a várnagyok - Perényi Miklós életében Dacsó László és Fancsikay Mojzes - fegyveres szolgáikkal büntetlenül garázdálkodtak az egész vármegyében. "40 Erről tanúskodik Hunyadi János Ugocsa hatóságához 1451. május 25-én írt levele. Ebben a kormányzó kéri, hogy vizsgálják ki azt az ügyet, amelyben a Perényi fiak birtokjogi okleveleket raboltak el Tóth János özvegyének szőlősi házából, amiket Nyalábvárában elégettek. ${ }^{41}$

1471. július 21-én a leleszi konvent előtt Perényi János fiai, Jób és Gábor visszafizették a 32000 forintot a Báthoryaknak a zálogosítás miatt. ${ }^{42}$ A Nyalábvár újra teljes joggal a Perényi családhoz került.

Mátyás király halála után a Perényi család gyorsan emelkedett a ranglétrán és sikerült Ugocsa vármegyében is megszilárdítaniuk hatalmukat. Ezt a tényt igazolni látszik az is, hogy egészen az 1514-es parasztlázadásig nem szólnak a dokumentumok Nyalábvárról. A parasztlázadás nyalábvári eseményeiről egy 1515. május 15-én kelt, Ugocsa megye hatóságának Ulászló királyhoz intézett leveléböl tudunk. ${ }^{43}$ Ebből kiderül, hogy a lázadó parasztok Nyalábvár ostromára készültek: a vár kapuja elé szalmát és fát hordtak és azt fel is gyújtották. A vád szerint a parasztok Sásvári Vörös Gergely tanácsára gyújtották fel a vár kapuját. A huszti várba sikerült belopózni Csomay Benedeknek és Péterfalvy Zsupán Pálnak, akik tájékoztatták a vár védőit Nyalábvár ostromáról. A parasztok megtudták ezt és félve Perényiék támadásától, elvonultak Nyaláb alól. ${ }^{44}$

\footnotetext{
${ }^{36}$ ZSO X. 604. sz., BAKÁCS ISTVÁN: Iratok Pest megye történetéhez. Oklevélregeszták, 1002-1437. (Pest Megye Múltjából sorozat 5.) Bp., 1982. 1411. sz.

${ }^{37}$ Perényi Lt. 385. sz.

${ }^{38}$ KomÁromy: i. m., 31.

${ }^{39}$ Perényi Lt. 472. sz.

${ }^{40}$ KoMÁromy: i. m., 33.

${ }^{41}$ C. TÓTH NORBERT: Ugocsa megye hatóságának oklevelei (1290-1526) Bp., 2006. 159. sz.

${ }^{42}$ KomÁromy: i. m., 32., PCSL 546-547. sz.

${ }^{43}$ C. То́TH: Ugocsa., 139. sz.

${ }^{44}$ KomÁROMY: i. m., 37.
} 
Az erődítményben jókora kár keletkezhetett, mivel egy 1516. március 5-én ${ }^{45}$ kelt okirat arról számol be, hogy Perényi Gábor, a vár tulajdonosa, 12000 aranyforint kölcsönt vett fel Frangepán Gergely kalocsai-bácsi érsektől. A kölcsön nem csak a vár felújításához volt szükséges, hanem a szőlősi házainak újjáépítéséhez is. Komáromy szerint a vár alsó részének a kapuja teljesen elégett. ${ }^{46}$ Az összeg mértékéből arra következtethetünk, hogy a várban jelentős károk keletkeztek, amiket ki is javítottak.

A parasztháború után igen keveset hallunk a várról. 1517-ből ${ }^{47}$ ránk maradt egy okirat, mely egy 24 évvel korábbi peres üggyel foglalkozik. Ám a továbbiakban igen szükszavúak a ránk maradt források. ${ }^{48}$ Komáromytól értesülünk arról, hogy a mohácsi csatában Perényi Gábor életét veszti, majd a zavaros időkben özvegye birtokolja a várat, mely ekkor a béke szigete. ${ }^{49}$

1570. szeptember 15-én még Nyalábvárban íródott azon dokumentum, melyben Perényi István ugocsai ispán Dolhai Györgynek Szőlősön levő szőlőjét minden tized és kilenced fizetés alól felmenti. ${ }^{50}$ 1575-ben meghalt Perényi István és a vár az özvegyre, ruszkai Dobó Annára szál. Az özvegy halála után a várat Dobó Ferenc birtokolja, aki egyben Perényi Zsófia gyámja is. A század végére száll vissza a Perényi család férfi ágára az erődítmény. ${ }^{51}$ Komáromy arról számol be, hogy a 17. század folyamán a vár történetével kapcsolatban nem sok dolgot lehet megemlíteni. ${ }^{52}$ Tőle értesülünk arról is, hogy a vár pusztulását a Wesselényi összeesküvésnek köszönhette. 1671. augusztus 9-én értesíti az udvar Perényi Gábort, Ugocsa megye föispánját, hogy mi fog történni a Nyalábvárral, s valóban a következő évben lerombolták. ${ }^{53}$ Ezt igazolja azon okirat is, mely 1674. július 3-án íródott, melyben „...Majos Ferenczczel Nyaláb alá, $s$ ott tanálván a két úrfiat Perényi Jánost $s$ Perényi Pált, Pál elszaladt Nyalábba $s$ a pusztában megmaradt..." 54

De hogyan is nézhetett ki a vár? Egykori alaprajzok hiányában a legtöbb adattal a régészeti ásatások szolgálnak. Az ungvári nemzeti egyetem régészei 2007-2011 között végeztek ásatásokat a kárpátaljai váraknál és várromoknál. Többek között a királyházai Nyalábvárnál. A várdomb földrajzi adottságairól már a fentiekben

\footnotetext{
${ }^{45}$ Perényi Lt. 757. sz.

${ }^{46}$ KoMÁROMY: i. m., 37.

${ }^{47}$ Perényi Lt. 794. sz.

${ }^{48} 1529$ után Frangepán Katalin meghívására Nyalábvárban nevelősködött Komjáthy Benedek, aki részben itt fordította le az Epistolae Pauli lingua Hungarica donatae. Az Zenth Paal leueley magyar nyeluen, az 1533-ban első teljes szövegében magyarul kiadott nyomtatvány szövegét. (A Szerk.) Ld. Epistolae Pauli lingua Hungarica donatae: az Zenth Paal leueley magyar nyeluen. Szerk.: Mezey András - Pelczéder Katalin - Kocán Béla. Reprint, Bp., 2013.

${ }^{49}$ KOMÁROMY: i. m., 38-39.

${ }^{50}$ IVÁNYI BÉLA: A római szent birodalmi széki gróf Teleki-család gyömröi levéltára. Szeged, 1931. 569. sz.

${ }^{51}$ KOMÁROMI: i. m., 40-41.

${ }^{52}$ Uo. 41.

${ }^{53}$ Uo. $41-42$.

${ }^{54}$ GÉRESI KÁLMÁN: A nagy-károlyi gróf Károlyi-család oklevéltára IV. Bp., 1887. 503-505.
} 
említést tettem. A dombot a Fekete- és az Avas-hegy öleli körbe. A vár az 52 méter magas domb északi részének meredek leejtőjének tetején helyezkedett el, alapterülete: 52 x 47 méter volt. Az erődítménytől 30 méterre egy védelmi vonal volt kialakítva. A várdomb déli, lankás oldalán egy - háromszög alapú 10,15 x 9,65 méter alapterületü - örtorony volt hivatott védeni a várat, ami a várba vezető utat is felügyelte. Maga a vár két részből állott: alsó és felső várból. A bejárat az alsó várrész délkeleti részén volt található, innen lehetett bejutni a felső várrészbe. Az alsó és felső várrész között 3-4 méteres szintkülönbség volt. A falak vastagsága 22,5 méter, magasságuk akár a 10 métert is elérte. ${ }^{55}$

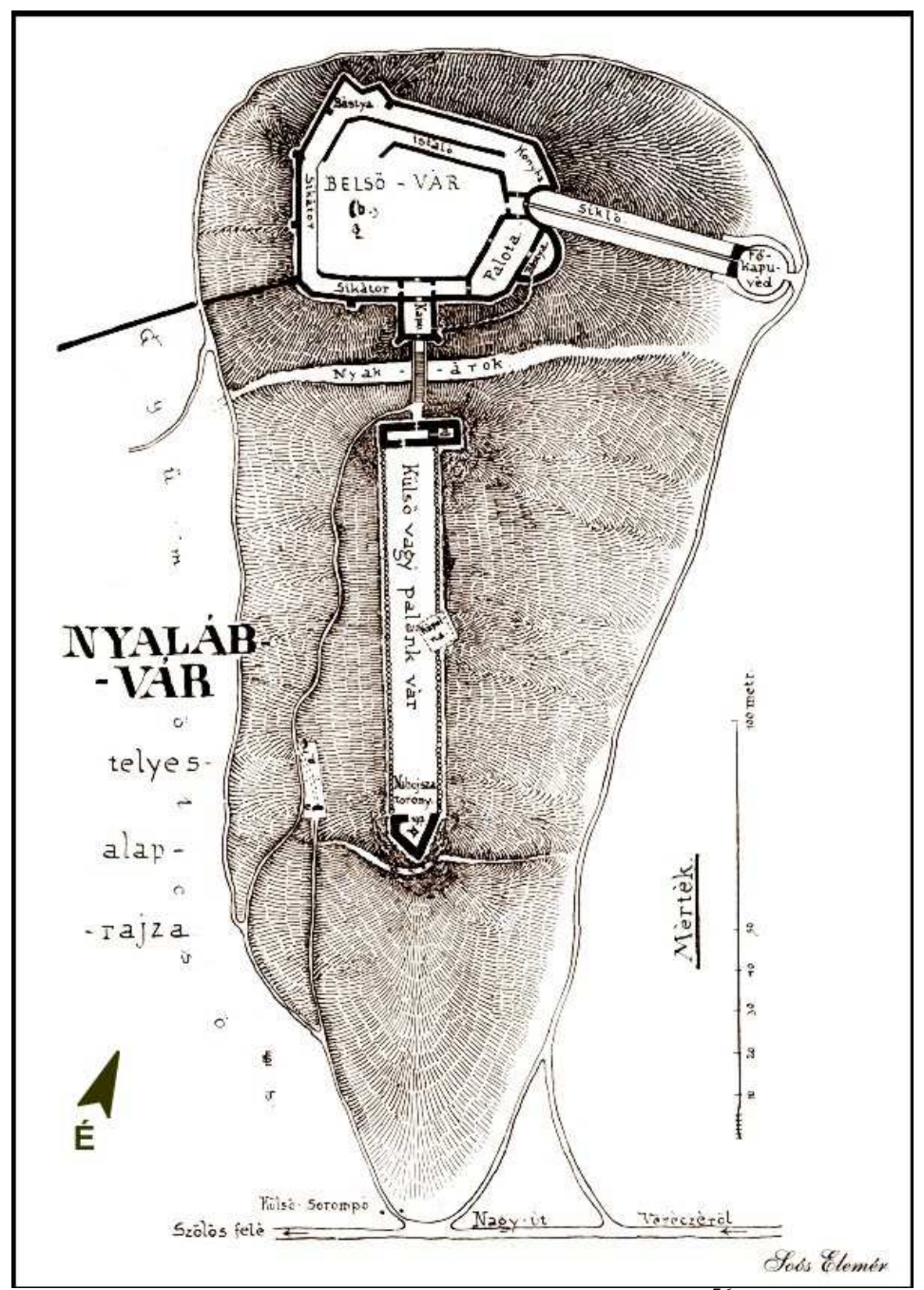

1. kép. Nyalábvár alaprajza. ${ }^{5}$

\footnotetext{
${ }^{55}$ ПРОХНЕНКО, И.А., МОЙЖЕС, В.В., ГОМОЛЯК, Е.М: i. m., 213.

${ }^{56}$ Soós Elemér rajza. Forrás: http://jupiter.elte.hu/111veglegesvar/alaplap.php? (letöltés ideje: 2014. december 1.)
} 
Továbbra is kérdéses, hogy mikor is épülhetett fel a királyházi Nyalábvár. A vár építésének kezdetét jelző dokumentum az idők folyamán vagy eltủnt, vagy valamelyik levéltár fel nem kutatott részlegében pihen. Saját magam az 1290-es évekre datálom a vár felépülését. Abban egyetérthetünk Komáromy Andrással, hogy a király részére Nyalábvár a huszti vár felépüléséig volt fontos, de mint másodlagos védelmi vonal, továbbra is jelentős lehetett, mivel az uralkodó még 1355-ben a várhoz tartozó vendégnépeket kiváltságokban részesíti. A dinasztiák váltakozása folyamán a vár nemesi családok kezébe kerül. 1376-ban Drág vajda szerzi meg a Nyaláb várat, majd pedig 1405-ben véglegesen a Perényi család birtokába kerül. A vár jelentősége a 16-17. századra felértékelődik. A vár pusztulását végül a királyi udvar dühe okozta. 1672-ben végleg megszünik erődítményi funkciója a Nyalábvárnak. A vár történetének pontosabb megismeréséhez további levéltári és régészeti kutatásokra van szükség. 